Systemy Logistyczne Wojsk

Zeszyt 55 (2021)

ISSN 1508-5430, s. 79-100

DOI:

Military Logistics Systems

Volume 55 (2021)

ISSN 1508-5430, pp. 79-100

DOI:
Instytut Logistyki

Wydział Bezpieczeństwa, Logistyki i Zarządzania

Wojskowa Akademia Techniczna

w Warszawie

Institute of Logistics

Faculty of Security, Logistics and Management Military University of Technology

in Warsaw

\title{
1st Pomeranian Logistics Brigade in 2004-2021st
}

\section{Pomorska Brygada Logistyczna w latach 2004-2021}

\author{
Jakub Andrzej Konwerski \\ kuba.konwerski@gmail.com; ORCID: 0000-0002-7527-1177 \\ Dowództwo 1 Brygady Logistycznej, Pion Logistyki, Sekcja Materiałowa, Polska \\ Anna Gackowska \\ 1blog.stirw@ron.mil.pl; ORCID: 0000-0003-3292-1958 \\ Dowództwo 1 Brygady Logistycznej, Pion Logistyki, Sekcja Transportowa, Polska
}

\begin{abstract}
Abstrakt. The aim of the article is to analyze the tasks performed by the 1st Pomeranian Logistics Brigade from Bydgoszcz with particular emphasis on the functions performed in the framework of international cooperation. The result of such a defined objective is the statement that the subject of the research is a military unit of the system of logistic support of the Armed Forces of the Republic of Poland, and the subject is selected tasks that were performed by it from 2015 to 2021 in the area of responsibility and the place of performing the function of the National Support Element for subdivisions. The main research problem is to answer the question - what is the role of 1st LOG BDE in the logistic support system of the Polish Armed Forces and how do the tasks carried out by it, affect the logistic security of the Polish Armed Forces? Various research methods have been used to solve the research problem including observation, synthesis, deduction and graphical methods of data presentation. Research hypothesis: It is assumed that the analysis and evaluation of the tasks carried out by the 1st Logistics Brigade allows to confirm that it is a key link in the logistic support system of the Polish Armed Forces. The article consists of two main parts. In order to make the reader familiar with the specificity of the unit, the first part, in general, discusses the mission, capabilities and structure of the brigade. The second part describes in detail its role in the implementation of alliance commitments. The method of logistic support of Polish Military Contingents was presented and on the example of an international exercise under the code name TRIDENT JUNCTURE 2015, which illustrated the support of sub-units as part of the NATO Response Force. The analysis of data and own experience allowed to formulate conclusions in which the 1st Logistics Brigade was identified as an important link in the implementation of logistics support tasks for the Polish Armed Forces.
\end{abstract}

Stowa kluczowe: logistics, PMC logistic support, the 1st Pomeranian Logistics Brigade, NATO Response Force 


\begin{abstract}
Celem artykułu jest analiza i ocena realizacji zadań przez 1 Pomorską Brygadę Logistyczną z Bydgoszczy ze szczególnym uwzględnieniem wykonywanych funkcji w ramach współpracy międzynarodowej w aspekcie zapewnienia bezpieczeństwa logistycznego Sił Zbrojnych RP. Skutkiem tak określonego celu jest stwierdzenie, że podmiotem badań jest jednostka wojskowa systemu zabezpieczania logistycznego SZ RP, a przedmiotem wybrane zadania jakie były przez nią wykonywane w latach 2015-2021 w rejonie odpowiedzialności oraz miejscu pełnienia funkcji Narodowego Elementu Wsparcia (NSE) dla pododdziałów. Zasadniczym problemem badawczym jest udzielenie odpowiedzi na pytanie: jaka jest rola 1 BLog w systemie zabezpieczenia logistycznego SZ RP oraz jak realizowane przez nią zadania wpływają na bezpieczeństwo logistyczne SZ RP? Do rozwiązania problemu badawczego zostały wykorzystane różne metody badawcze m.in.: obserwacje, synteza, dedukcja oraz metody graficzne przedstawienia danych. Hipoteza badawcza: Analiza i ocena zadań realizowanych przez 1 BLog pozwala na potwierdzenie, że jest ona kluczowym ogniwem w systemie wsparcia logistycznego Sił Zbrojnych RP. Artykuł składa się z dwóch zasadniczych części. W celu przybliżenia czytelnikowi specyfiki jednostki, w pierwszej części, ogólnie omówiono misję, możliwości oraz strukturę brygady. W części drugiej szczegółowo opisano jej rolę w zakresie realizacji zobowiązań sojuszniczych. Przedstawiono sposób zabezpieczenia logistycznego Polskich Kontyngentów Wojskowych (PKW) oraz na przykładzie ćwiczenia międzynarodowego pod kryptonimem TRIDENT JUNCTURE 2015 zobrazowano wsparcie pododdziałów wydzielanych w ramach Sił Odpowiedzi NATO. Analiza danych oraz doświadczenia własne pozwoliły na sformułowanie wniosków, w ramach których określono 1 BLog jako istotne ogniwo realizacji zadań zabezpieczenia logistycznego na rzecz SZ RP
\end{abstract}

Keywords: logistyka, zabezpieczenie logistyczne PKW, 1 Brygada Logistyczna, Siły Odpowiedzi NATO

\title{
Introduction
}

The history of armed conflicts proves that the factor determining success on the battlefield is adequate provision of supplies and ensuring the provision of services for troops. There is a need to search for solutions enabling proper security of troops and efficient logistics, contributed to the creation of the concept of a logistics system.

In the logistic doctrine of the Polish Armed Forces, the following definition was established and adopted: "The logistic system is an ordered set of elements of the organizational structure (subsystems and functional areas), the purpose of which, as well as mutual relations, ensure the conditions for the proper functioning of the armed forces in times of peace, crisis and war"(Doktryna Logistyczna Sił Zbrojnych RP D-4(B) wersja 2., 2019, s.19.).

The organizational unit in the Polish Armed Forces, which is responsible for the logistical support of Polish soldiers in the country and abroad, is the Armed Forces Support Inspectorate, which in its organizational structure has many military units and institutions carrying out its tasks, including $1^{\text {st }}$ Pomeranian Logistics Brigade (LOG BDE) in Bydgoszcz.

From the beginning of the brigade's existence, the soldiers serving in it follow the motto: "Logistics sets off first and returns last". The paraphrase of the above-mentioned The text placed on the plinth of the monument at the entrance to the barracks reminds us of the duties and obligations of logisticians who always reach the areas where tasks have been planned first. Then, after the implementation of projects, they prepare the area where troops are stationed to the initial state and leave it as the last one. 


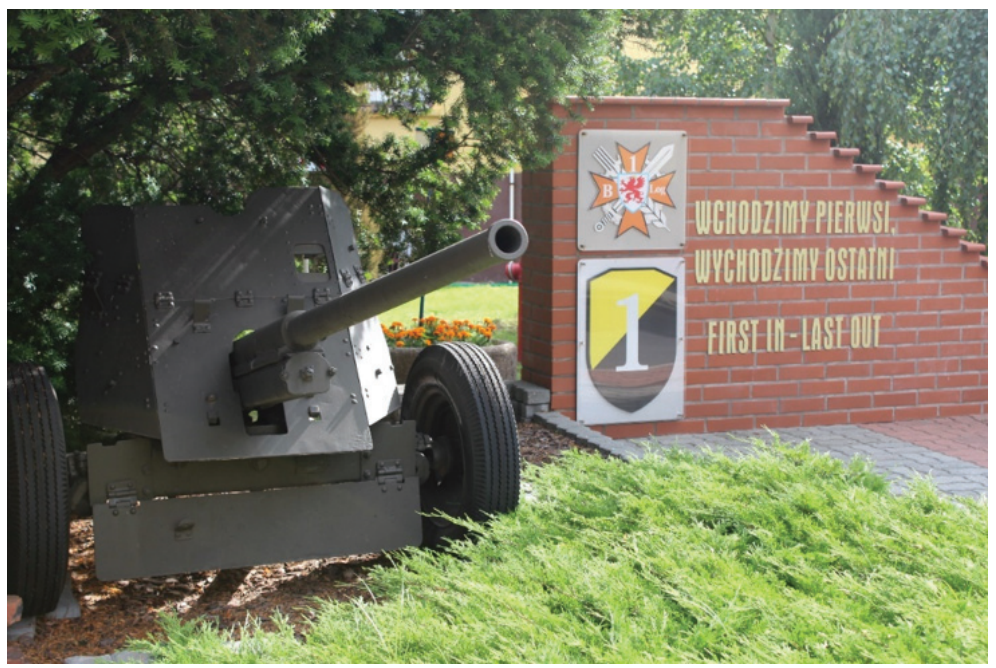

Fig. 1. Mural with the $1^{\text {st }}$ LOG BDE Commander soldiers motto Source: Photography PFC Jagoda Markiel

The aim of the article is to analyze and evaluate the implementation of tasks by the 1st Pomeranian Logistics Brigade from Bydgoszcz, with special emphasis on the functions performed as part of international cooperation in terms of keeping the logistic security of the Polish Armed Forces.

The research problem was formulated in the form of a question: What is the role of $1^{\text {st }}$ LOG BDE in the logistic support system of the Polish Armed Forces and how do the tasks carried out by it, affect the logistic security of the Polish Armed Forces?

The result of such evaluation is the statement, that the subject of the research is a military unit of the Polish Armed Forces, and selected tasks that were performed by it in 2015-2021 in the area of responsibility in country and activity of the function of the National Support Element (NSE) for subunits abroad.

The scope of the site is the area of responsibility in which the logistic support was carried out. The main research area is the PMC area, for which the military economic branch (MEB) is $1^{\text {st }} \mathrm{LOG} \mathrm{BDE}$, and the region of Spain, where the exercise under the code name TRIDENT JUNCTURE-2015 was participated.

The time range covers tasks carried out in 2015-2021.

The presented aim and research problem made it possible to formulate the research hypothesis: It is assumed that the analysis and evaluation of the tasks carried out by the 1st Logistics Brigade allows to confirm that it is a key link in the logistic support system of the Polish Armed Forces.

The article is analytical in nature. Active participation in the described projects made it possible to use the method of observation. In order to discuss the collected data, inference and synthesis were used. Statistical, tabular and graphical methods 
were used to illustrate the data. The above solutions made it possible to discuss the research problem of the role of $1^{\text {st }}$ LOG BDE in the logistics support system of the Armed Forces.

The literature on the subject of research is not extensive. The instructions and regulations of the Ministry of National Defense define the general principles of the logistics of the Armed Forces. There is no study relating to the implementation of tasks by the $1^{\text {st }}$ Pomeranian Logistics Brigade.

\section{Mission, tasks, $1^{\text {st }}$ Logistics Brigade organizational structure}

The $1^{\text {st }}$ LOG BDE is a tactical union reporting directly to the Head of the Polish Armed Forces Support Inspectorate.

The basis for the formation of the brigade were:

- Decision of the Minister of National Defense No. PF-57/Org./P1 of October 22, 2003;

- Order of the Chief of the General Staff of the Polish Armed Forces No. PF-376/Org./P1 of November 7, 2003;

- Order of the Land Forces Commander No. PF-222 of December 11, 2003;

- Order of the Commander of the Pomeranian Military District No. PF-4 of January 7, 2004.

The above-mentioned documents determined the date of its creation until June 30, 2004 [ $1^{\text {st }}$ Logistics Brigade, (2021), accessed on July 18, 2021].

Over the years, the organizational structure of $1^{\text {st }}$ LOG BDE has changed with the evolution of the logistics system of the Armed Forces and has adapted to the tasks entrusted to it.

Currently, the military units shown in Figure No. 2 are subordinate to the Commander of the $1^{\text {st }}$ Pomeranian Logistics Brigade. Eight subordinate battalions are stationed in garrisons in provinces:

- Kuyavian-Pomeranian Voivodeship in Bydgoszcz (Command $1{ }^{\text {st }}$ LOG BDE, $1^{\text {st }} \mathrm{HQs}$ battalion, $1^{\text {st }}$ logistics battalion, $2^{\text {nd }}$ logistics battalion);

- Warmian-Masurian Voivodeship in Giżycko ( $112^{\text {th }}$ maintenance battalion);

- West Pomeranian Voivodeship in Glewice ( $3^{\text {rd }}$ logistics battalion);

- Pomorskie in the town of Czarne $\left(11^{\text {th }}\right.$ recovery battalion and $52^{\text {nd }}$ maintenance battalion);

- Mazowieckie in Ciechanów ( $1^{\text {st }}$ storage battalion).

The main tasks carried out by $1^{\text {st }}$ LOG BDE include:

- allocating forces and resources to the National Support Element (NSE) to designated military units of the Armed Forces participating in military missions abroad;

- timely logistical support for PMC; 
- implementation of supplies, transport, service and repair tasks for operational troops in the area of responsibility;

- fulfillment of allied obligations under the Objectives of the NATO Armed Forces and the NATO Response Force;

- maintaining the Polish Armed Forces Task Force ready for use;

- providing logistical support to state institutions in crisis situations;

- implementation of the training process in order to prepare the brigade to perform its tasks, as intended.

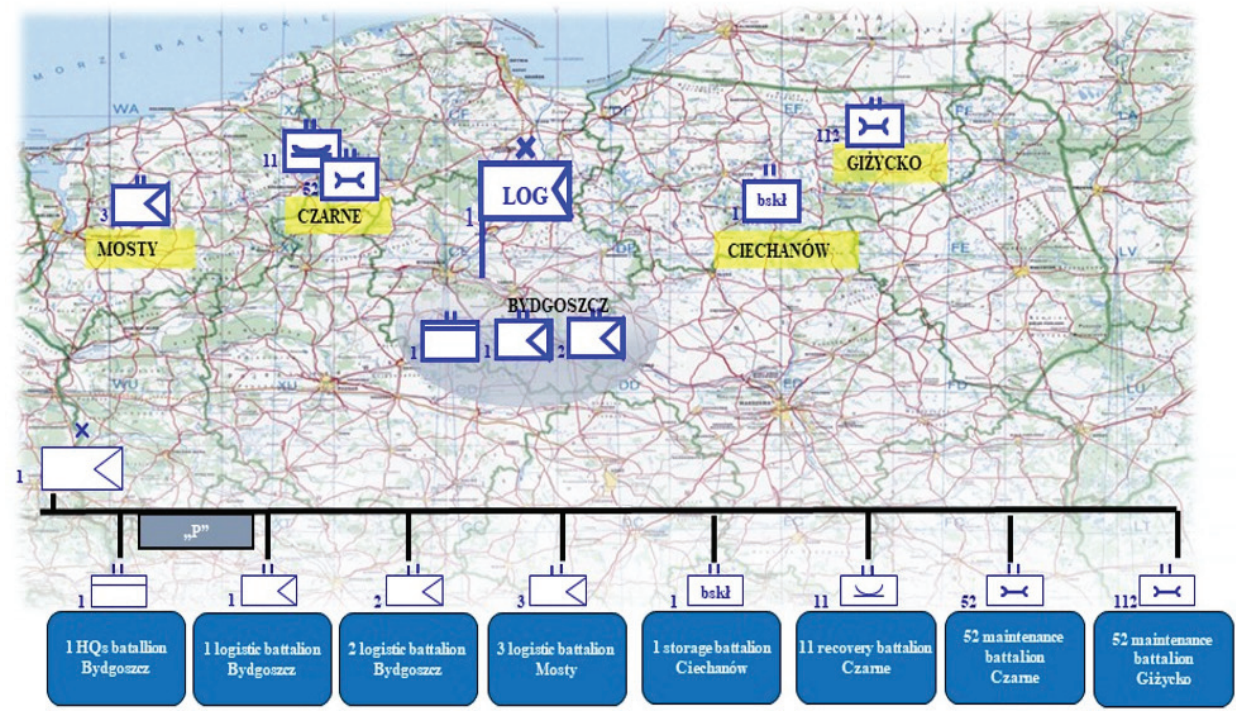

Fig. 2. Units subordinate to the $1^{\text {st }}$ LOG BDE Commander Source: Prepared by the authors

The equipment and armaments of the brigade battalions are strictly adapted to the tasks performed. The HQs battalion organizes the functioning of the $1^{\text {st }} \mathrm{LOG} B D E$ Command, and during the war he was preparing a brigade command post. The logistic potential is represented by three logistic battalions, which are designed to transport supplies for operational troops. Their resources include over 200 heavy-duty trucks and 160 fuel tanks. The maintenance battalions are prepared to carry out maintenance and repair tasks up to the R-3 level, i.e. those whose repair time is up to 120 man-hours. In times of peace, v. battalions carry out military equipment repairs as part of the Annual Military Equipment Repair Plan, which in 2021 includes the possibilities presented in Table 1. The basic equipment is Mobile Repair Workshops, Vehicle Service Workshops, Vehicle Repair Workshops, Field Charging Stations, Welding and Sheet Metal Workshops, Weapon Equipment Repair Workshops and Electronics and evacuation equipment. 
The equipment recovery battalion uses, among others, Technical support vehicles, low-loader sets and heavy wheeled evacuation and technical rescue vehicles. The storage battalion is designed to receive, store and distribute material and combat assets. It is equipped with fuel installations and rubber tanks on the basis of which you can build field MPS depots, tanks for water storage and distribution, and reloading equipment.

Considering the above, military units subordinate to $1 \mathrm{BLog}$ have the capabilities to perform the tasks presented in Table 1.

Table 1. $1^{\text {st }}$ Logistics Brigade possibilities of the implementing tasks

\begin{tabular}{|c|c|}
\hline \multicolumn{2}{|c|}{ TRANSPORT POSSIBILITIES } \\
\hline Material means & $2700 \mathrm{t}$ \\
\hline Petroleum, oils and lubricants (POL) & $1800 \mathrm{~m}^{3}$ \\
\hline \multicolumn{2}{|c|}{ EVACUATION POSSIBILITIES } \\
\hline Low-loader sets evacuation & 27 military units \\
\hline Armored trucks evacuation & 6 military units \\
\hline \multicolumn{2}{|c|}{ SERVICE AND REPAIR POSSIBILITIES } \\
\hline Tanks & 4 pcs. $/ 24 \mathrm{~h}$ \\
\hline Armoured Fighting Vehicles & 5 pcs. $/ 24 \mathrm{~h}$ \\
\hline Armoured personnel carrier & 4 pcs. $/ 24 \mathrm{~h}$ \\
\hline Wheeled vehicles & 4 pcs. $/ 24 \mathrm{~h}$ \\
\hline Artillery and mortar equipment & 4 pcs. $/ 24 \mathrm{~h}$ \\
\hline Engineering equipment & 2 pcs. $/ 24 \mathrm{~h}$ \\
\hline Small arms & 55 pcs. $/ 24 \mathrm{~h}$ \\
\hline \multicolumn{2}{|c|}{ STORAGE POSSIBILITIES } \\
\hline Food & $460 \mathrm{t}$ \\
\hline Water & $843 \mathrm{~m}^{3}$ \\
\hline POL in tanks & $461 \mathrm{t}$ \\
\hline Combat measures & $169 t$ \\
\hline Technical material measures & $77 \mathrm{t}$ \\
\hline \multicolumn{2}{|c|}{ SERVICE CAPABILITIES } \\
\hline Fuel switching by field pipelines & Do $2000 \mathrm{~m}^{3} / 24 \mathrm{~h}$ \\
\hline Laundry Services & $1800 \mathrm{~kg} / 24 \mathrm{~h}$ \\
\hline Bath Services & $5700 \mathrm{pax} / 24 \mathrm{~h}$ \\
\hline Feeding (with field kitchen) & $1620 \mathrm{pax} / 24 \mathrm{~h}$ \\
\hline Baking bread & 3564 pcs./ $24 \mathrm{~h}$ \\
\hline
\end{tabular}

Source: Prepared by the authors based on data from the $1^{\text {st }}$ LOG BDE (Logistics Section) 
The table number 2 shows the implementation of transports and repairs for the operational troops in 2018-2020. In the analyzed period, annually, on average, 1113 vehicles were transported, 29000 tons of materials and 321 units of military equipment were improved.

Table 2. Implementation of transports and repairs for the operational troops in 2018-2020

\begin{tabular}{|c|c|c|c|}
\hline \multirow{2}{*}{ Year } & \multicolumn{2}{|c|}{ Transported } & \multirow{2}{*}{$\begin{array}{c}\text { Number of streamlined } \\
\text { military vehicles }\end{array}$} \\
\cline { 2 - 3 } & Number of military vehicles & Mass of material measures [t] & 451 \\
\hline 2018 & 946 & 27135 & 262 \\
\hline 2019 & 1495 & 30574 & 281 \\
\hline 2020 & 976 & 30624 & 26 \\
\hline
\end{tabular}

Source: Prepared by the authors based on data from the $1^{\text {st }}$ LOG BDE (Logistics Section)

2019 saw a significant increase in the number of transported military equipment until 2018 due to the involvement of $1^{\text {st }}$ LOG BDE in the logistics of military exercises, including DRAGON-19 and CAPABLE LOGISTICIAN-19. The medium-term growth rate is 1.57 every year. The growth rate of the transported mass of material assets slightly increases over the years and amounts to $5.7 \%$. The number of improved military equipment decreased on average by $21 \%$ year by year. This is a direct result of the fact that in 2019, 2 renovation battalions were lost from the structures of 1st Logistics Brigade $\left(8^{\text {th }}\right.$ maintenance battalion from Kołobrzeg and $16^{\text {th }}$ maintenance battalion from Elbląg).

It should be emphasized that the potential of the $1^{\text {st }} \mathrm{LOG} B \mathrm{BDE}$ is not only determined by soldiers, but also by employees of the Ministry of National Defense.

\section{The role of $1^{\text {st }}$ Logistics Brigade in the implementation of allied commitments}

Among the tasks carried out by the $1^{\text {st }}$ LOG BDE, allied obligations occupy a special place. It should be noted that the formation, training and maintenance of soldiers performing tasks under the PMC, NATO Response Force Kits and the allocation of forces and resources to the objectives of the NATO Armed Forces is an ongoing process.

Moreover, in recent years, soldiers have raised their qualifications through participation and logistical support for international exercises, including:

- TRIDENT JUNCTURE 15 - NSE for subunits training in Spain and Portugal;

- NUBLE JUMP 17 - NSE for subunits training in Romania;

- BRIGHT ARMOURED 17 - exercise observers; 
- SABER STRIKE 17 - separation of the operational group to participate in the exercise;

- $\quad$ TRIDENT JAVELIN 17 - reinforcement of the staffing of JLSG HQ (Joint Logistic Support Group Headquarters);

- TRIDENT JUNCTURE 18 - NSE for subunits training in Norway;

- $\quad$ BRILLIANT JOUST-18 - reinforcement of the JLSG HQ cast;

- CAPABLE LOGISTICIAN 19 - allocation of forces and resources to the Command of the Joint Logistics Support Group - JLSG HQ and RSOM (Reception, Staging, Onward, Movement). Ensuring the admission, stay and movement of troops and the provision of logistical support to units in the area of joint operations;

- BRILLIANT JUMP 20 and IRON WOLF 20 - separation of a heavy equipment transport company under SON 2020.

\section{PMC Logistic support}

The logistic security of the Polish Military Contingent is based on close coordination and cooperation between the coalition partners, using the principles of multinational logistics. It results from the need to reduce operating costs and provide logistic support in operations by international means, such as: Host Nation (HN), Lead Nation (LN), Specialist Nation (RSN) and Multinational Integrated Logistic Support (MILS).

As shown in Figure 3, PMC logistic support is a process of each phase of activities.

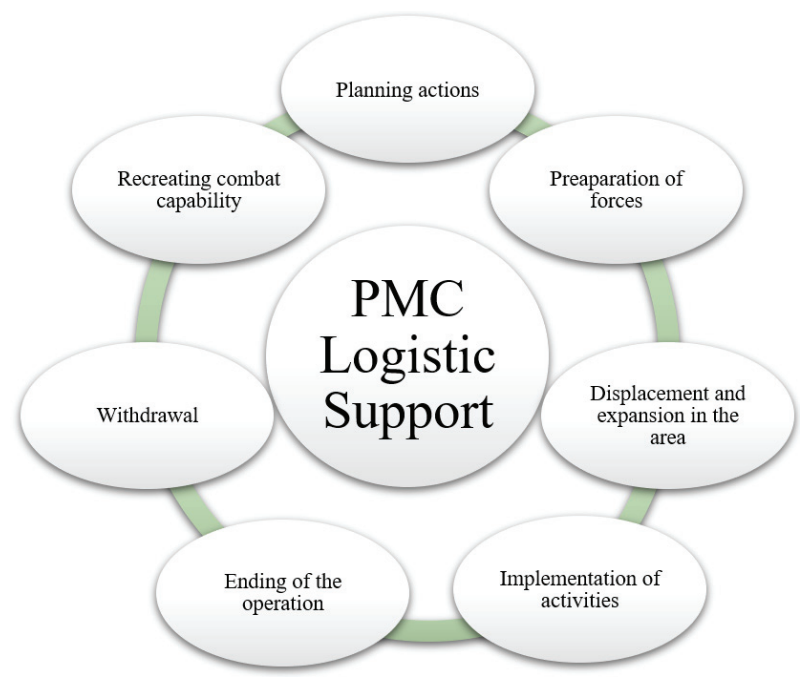

Fig. 3. Logistic support phases of conducted operations

Source: Prepared by the authors based on data from the (Grala, 2017, s 69) 
The following factors have an impact on the PMC logistic support process: the purpose and scope of operations, the combat composition of the forces, the type and intensity of operations, climatic and terrain conditions. The distance from domestic sources of supply and the availability of local market resources are of particular importance, as well as the possibility of support by multinational logistics, external contractors and the host country (Grala, 2017, p. 69). The breakdown of the basic sources of logistic resources is shown in Fig. 4.
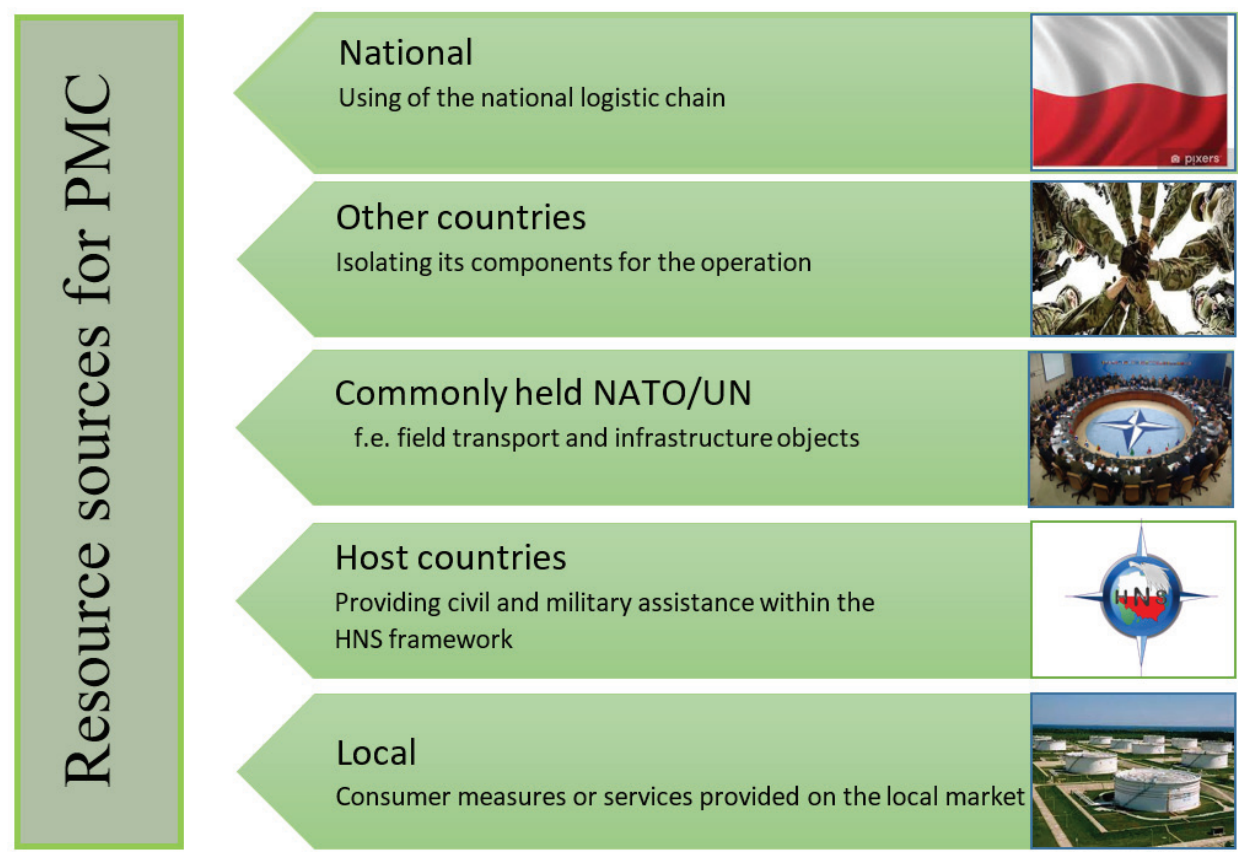

Fig. 4. Distribution of available logistics resources in the PMC

Source: Prepared by the authors based on data from the (Nyszk, 2009, s. 37)

\section{PMC Logistic Support Organized By $1^{\text {St }}$ Logistics Brigade}

For 17 years of operation of the 1st Pomeranian Logistics Brigade, over 3,700 soldiers participated in missions abroad as part of Polish Military Contingents in: Afghanistan, Chad, Iraq, Lebanon, Syria, Kosovo, Bosnia and Herzegovina, Republic of Mali, the Central African Republic and Latvia (1 Brygada Logistyczna, 2021, access of the day 18.07.2021). Many brigade soldiers participated in the missions several times. $1^{\text {st }}$ LOG BDE allocates forces mainly to the NSE. 
$1^{\text {st }}$ LOG BDE secures and provides - logistic support to the Polish Military Contingents (PMC), for which - at the same time it acts as the Economic Branch, i.e.:

- PMC KFOR in the Republic of Kosovo;

- PMC EUFOR in Bosnia and Herzegovina;

- PMC LATVIA;

- PMC IRAQ;

- PKW UNIFIL;

- PKW CAF.

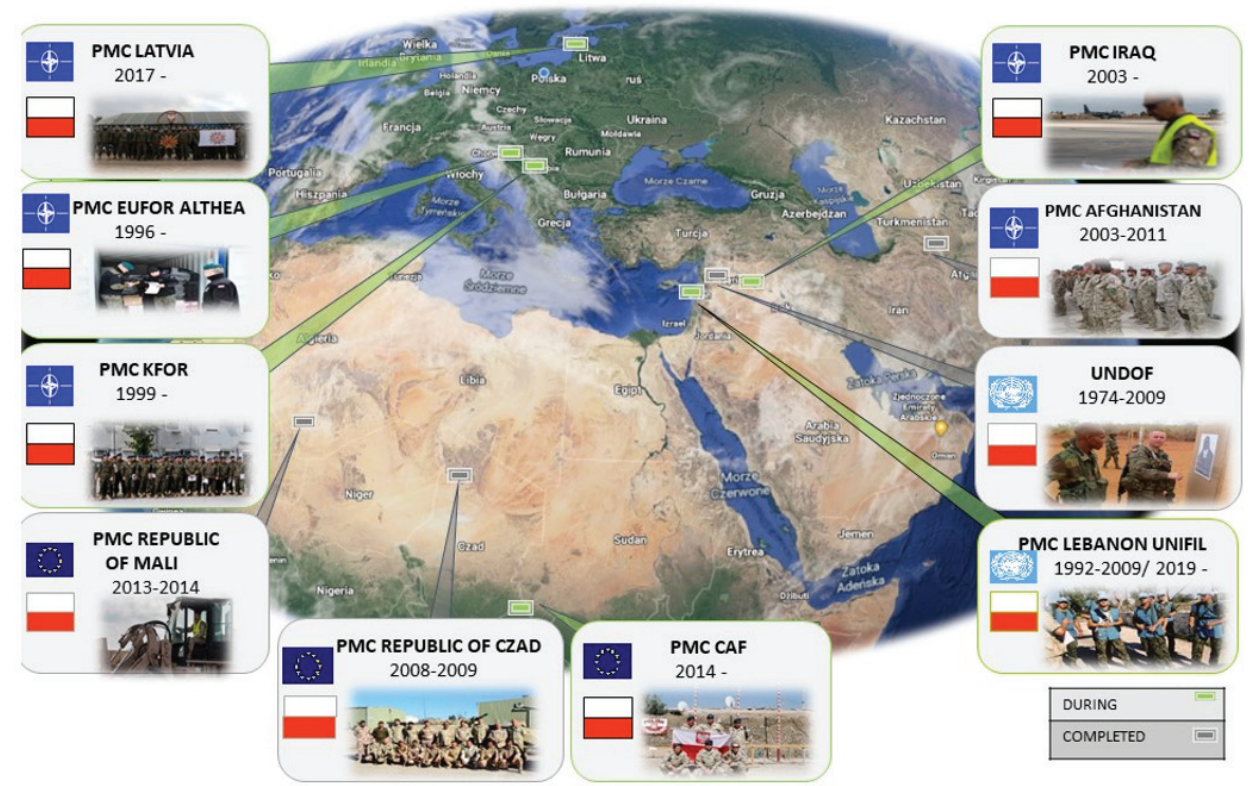

Fig. 5. Participation of the $1^{\text {st }}$ LOG BDE in the PMC

Source: Prepared by the authors based on data from the $1^{\text {st }}$ LOG BDE (Operational Section)

Currently, 43 soldiers are involved in the missions. 47 soldiers are participating in the process of preparing to participate in the next shifts of the PMC. It should be noted that in the continuous system, one shift of soldiers prepares for the mission, the second is during the mission, and the third restores the ability after the mission. In total, the number of soldiers involved in peacekeeping missions annually amounts to approximately 240 people.

The PMC's logistic support by $1^{\text {st }} \mathrm{LOG}$ BDE is carried out in accordance with the Plan of participation of a given contingent and the Operational Orders of the Armed Forces Operational Command.

Commander of the $1^{\text {st }}$ LOG BDE as the Commander of the Military Economic Branch for the PMC and trains the NSE. In addition, it carries out projects related 
to the material supply of the PMC from domestic resources, according to the priorities set by the Armed Forces Operational Command and the PMC Commander. In particular, it carries out the following tasks (Zasady prowadzenia gospodarki materiałowej i finansowej w Polskich Kontyngentach Wojskowych realizujących zadania poza granicami państwa, 2018, s. 17):

- analyzes the data on the state of the PMC logistic support and forecasts the needs in terms of national support;

- calculates the norm of stocks of material resources for the PMC and is responsible for their proper collection, distribution and storage in the country;

- requests changes to the position and tables of PMC receivables via Armed Forces Operational Command;

- supervises the management of materials at the PMC and analyzes the submitted needs;

- collects property and organizes transports to/from PMC;

- accepts soldiers evacuated to the country from the NSE. It organizes the transport of the withdrawn military equipment and supplies, and then directs them to military units, repair plants or warehouses, respectively.

The NSE Commander is responsible for the direct implementation of the tasks of the national logistic support of the PMC. In particular, it carries out the following tasks (Zasady prowadzenia gospodarki materiałowej i finansowej w Polskich Kontyngentach Wojskowych realizujących zadania poza granicami państwa, 2018, s. 19):

- defines the needs of the PMC in the field of national logistic support;

- plans, organizes and conducts (if the NSE includes a repair sub-unit) the repair and technical service of the military equipment which is the equipment of the PMC, in accordance with the rules and priorities specified by the PMC Commander;

- organizes the distribution of supplies to economic units of the PMC;

- maintains constant (working) contact with the MEB Commander and the Armed Forces Operational Command in the field of information on the needs of supplying and rotating military equipment;

- provides the Armed Forces Operational Command and the MEB Commander with information on the state of the PMC's logistic support;

- decides on the source of supply on the local market or in international organizations and purchases;

- procures means of supply and services provided with support by the HN or the LN;

- in agreement with the MEB Commander, reports the need for transport to the country of military equipment and material resources unnecessary at the PMC;

- organizes the transport subsystem at PMC. 
The functioning of PMC is organized on the basis of stationary infrastructure, residential containers, tent base and rental of real estate on the local market as part of the operation of multinational logistics. The facilities are equipped with the necessary accommodation and social and living equipment appropriate to the climatic conditions.

The energy security of the quotas is based on the stationary power grid of a given region. Due to the maintenance of an appropriate level of security, the military bases use power generators that ensure complete self-sufficiency and independence from local suppliers. They are contracted or constitute a full-time payment of the PMC.

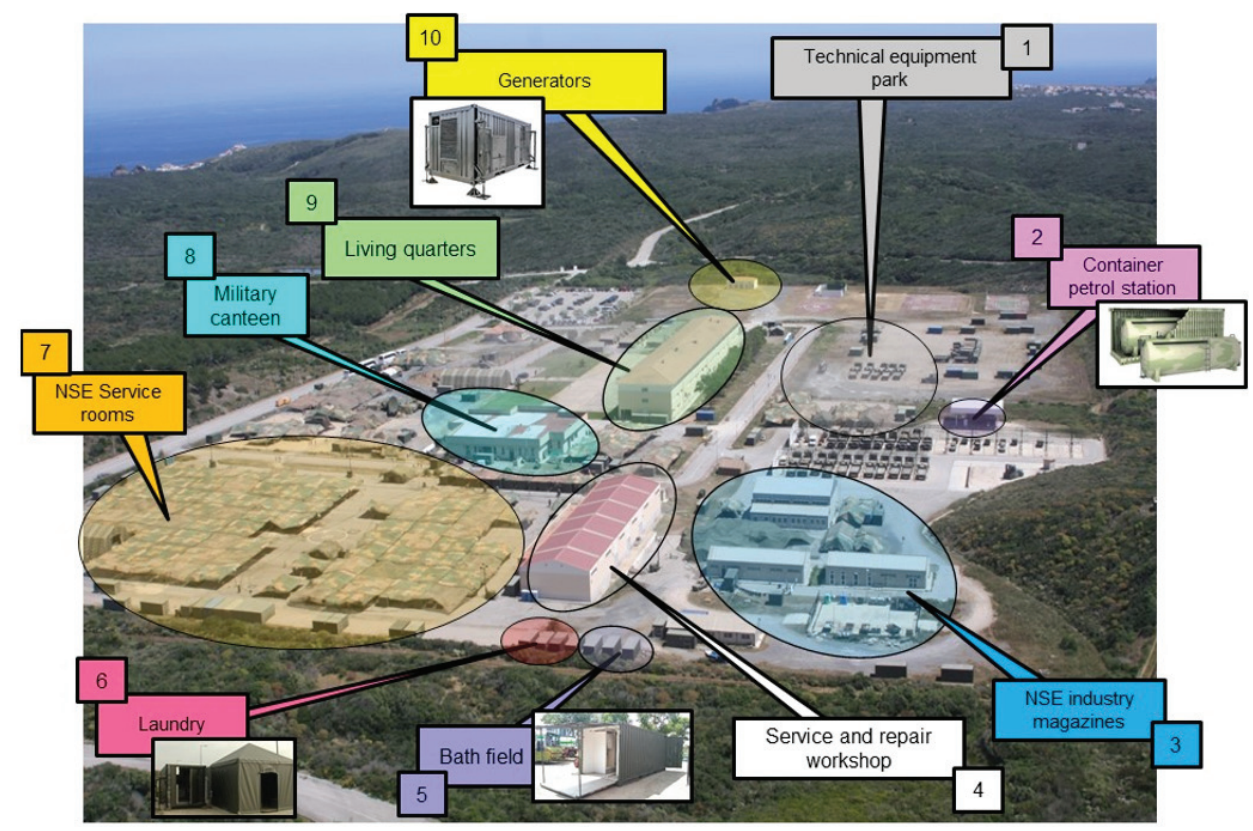

Fig. 6. An exemplary layout of the elements of the PMC base

Source: Prepared by the authors

The supply of means of supply to the PMC is based on the annual planning cycle and the submitted ad hoc demand. The annual requirement is met by the $1^{\text {st }} \mathrm{LOG}$ $\mathrm{BDE}$ Commander based on the monthly requirements of the NSE. When emergency needs arise, the NSE prepares and sends an ad hoc request to the MEB Commander. For an assortment that goes beyond the full-time and the table of amounts due to the time, the demand is preceded by appropriate PMC applications for introducing changes in the full time or in the table of amounts due. Subsequent changes to the NSE PMC conducts an analysis of unmet needs based on the list of unmet items of needs submitted by the MEB, submitted by the previous change. The analysis is 
sent back to the $\mathrm{MEB}$, indicating in detail the maintenance, resignation or change in the amount of funds required (Zasady prowadzenia gospodarki materiałowej i finansowej w Polskich Kontyngentach Wojskowych realizujących zadania poza granicami państwa, 2018, s. 6).

The implementation of the provision of material resources for PMC by $1^{\text {st }}$ LOG BDE is illustrated in Fig. 7 and is as follows:

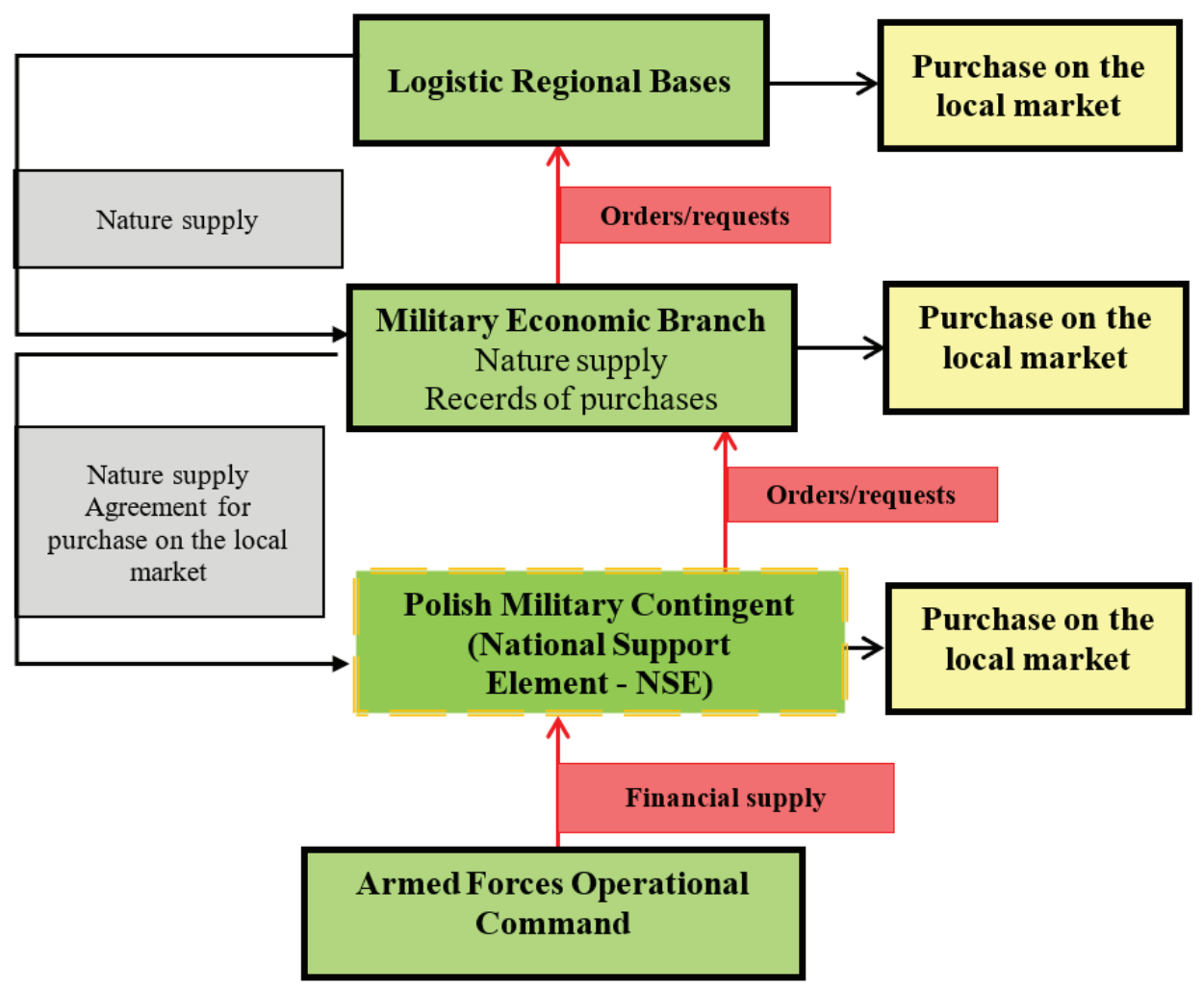

Fig. 7. PMC supply scheme

Source: Prepared by the authors based on data from the (Zasady prowadzenia gospodarki materiałowej i finansowej w Polskich Kontyngentach Wojskowych realizujących zadania poza granicami państwa, (2018), s. 21)

- units supplied by the NSE send the demand for technical materials / materials to the head of service/section in the NSE;

- the head of service analyzes the inventory in the NSE and the possibility of purchasing on the local market after obtaining the prior consent of the MEB;

- the MEB Commander can give purchase approval to NSE in the marketplace; 
- local or to issue technical material measures/materials in kind if he has them in his warehouse;

- in the absence of the required technical means of material / materials in the GI resources, the demand is sent to the Regional Logistics Bases for securing items that do not appear in the MEB. The Regional Logistics Base analyze its resources as well as the resources of the other three Regional Logistics Bases.

Securing contingents with combat assets and items of uniforms equipment is a national responsibility. The supply of ammunition is carried out on the basis of the requirements submitted by the NSE to the MEB. At PMC, the prescribed level of stocks is kept in container warehouses, the structure of which is shown in Fig. 8.

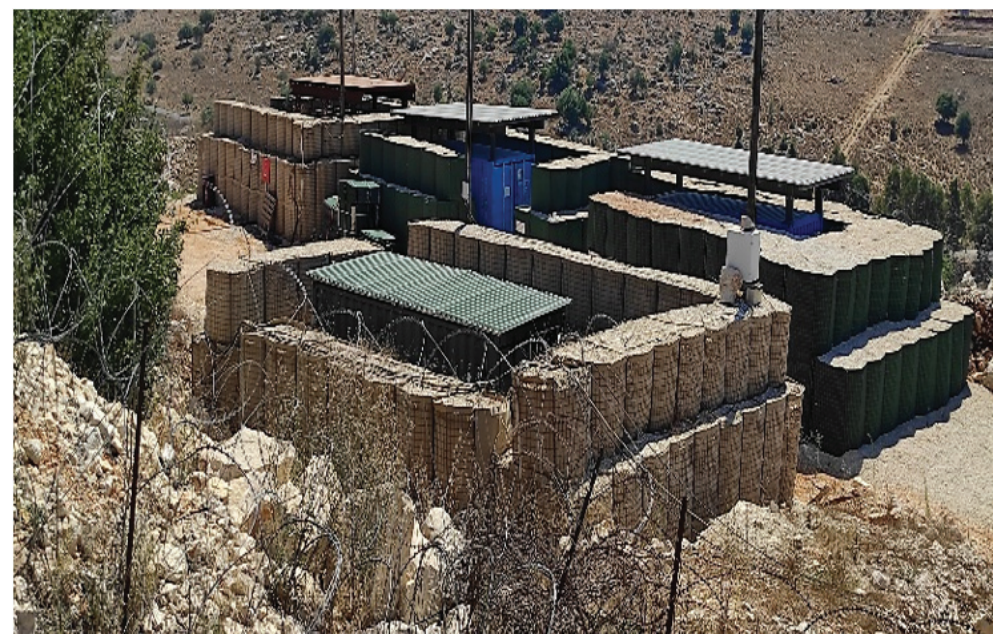

Fig. 8. Container storage of combat assets in the area of PMC UNIFIL Source: Prepared by the authors

The equipment of soldiers in items of uniforms equipment is adapted to the climatic conditions in a given region. In the theater of operations, on the basis of organized trade magazines, NSE maintains the prescribed level of stock of essential items, provided for securing the activities of the Polish Military Contingent. The required number of individual uniforms is expressed as a percentage of the full-time workforce. It should be noted that in the case of the PMC UNIFIL mission, the supply of berets, scarves and distinctive badges is the responsibility of the United Nations.

Supplying the quota with POL is based on the NSPA contractor. As shown in Fig. 9, the equipment is refueled on the basis of petrol stations, with the use of military field infrastructure or fuel tankers owned by the PMC. The supply of oils, greases 
and special products is carried out on the basis of the needs submitted by NSE and transferred by MEB from the country. The exception is PMC UNIFIL, where some of the basic lubricating products are secured by the United Nations.

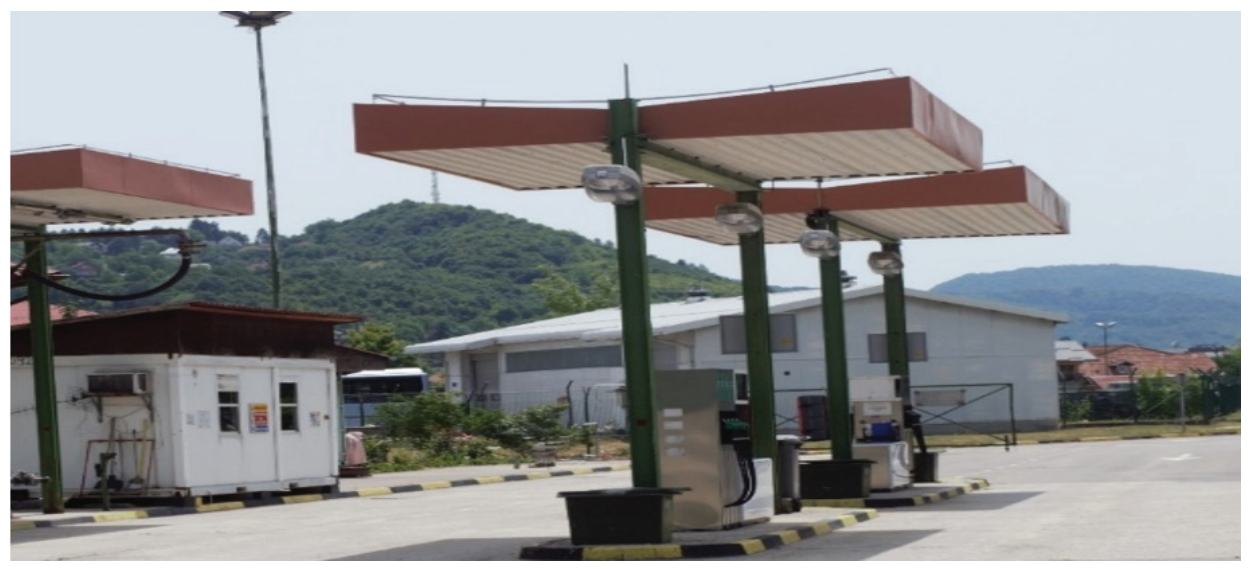

Fig. 9. Fuel stations on the premises of PMC EUFOR and PMC UNIFIL

Source: Prepared by the authors

Due to the necessity to ensure food safety and appropriate sanitary and epidemiological conditions, nutrition is organized solely on the basis of the coalition supply system of the state organizing and securing nutrition in the area of missions or civilian entities performing tasks for the PMC covered by sanitary supervision, resulting from the technical agreement (TA - Technical Agreement) of the mission and in accordance with the STANAG 2556 standardization agreement (Food safety, defense and production support of NATO operations). In addition, when performing tasks outside the base, nutrition is organized on the basis of individual field dry and concentrated land rations. It should be added that on the occasion of important national holidays and religious NSE organizes traditional meals. The semi-finished products are delivered to the PMC area as part of the food supply from the country or are sourced from the local market in accordance with applicable regulations (Zasady prowadzenia gospodarki materiałowej i finansowej w Polskich Kontyngentach Wojskowych realizujących zadania poza granicami państwa, 2018, s. 43-44; Przepisy o działalności służby żywnościowej DU-4.21.1 B, 2020, s.103-107).

Due to the intensified exploitation of military equipment, there are more operational faults than in the country. This requires having an adequate supply of tapes and service and repair capabilities, and a larger inventory of spare parts and consumables as well as repair kits are maintained. It should be noted that the storage space in the mission area is limited. The storage conditions for spare parts are shown in Figure 10. 


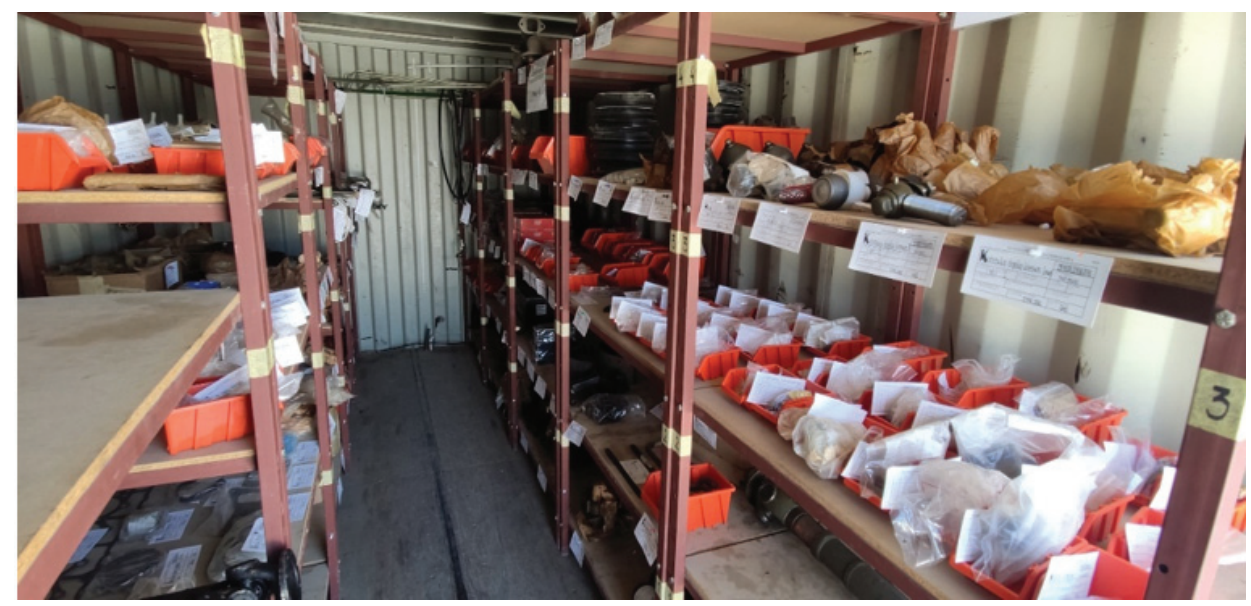

Fig. 10. Container warehouse of spare parts at PMC

Source: Prepared by the authors

Military equipment maintenance and repairs are carried out by maneuvering companies, soldiers of maintenance and repair workshops or with the use of local companies. For the equipment under warranty, the implementation of technical services, warranty inspections and repairs through the manufacturer's service was provided.

The need to direct staff for the implementation of specialized services $1^{\text {st }} \mathrm{LOG}$ $\mathrm{BDE}$ receives several weeks in advance. After analyzing the possibilities, the Commander of the $1^{\text {st }}$ LOG BDE decides to send the above-mentioned people with supplies transport or a commercial flight. Selected soldiers and employees for the PMC carrying out tasks in Europe must have current medical (periodic) examinations, and outside its area a health certificate allowing them to travel to the PMC area.

Fig. 11 shows the dynamics of changes in the deliveries made in 2019-2020 and illustrates the amounts of material resources delivered from January 2019 to June 2021 to the PMC region, being supplied by $1^{\text {st }}$ LOG BDE. Due to the protection of all the needs of PMC CAF by multinational logistics of the above-mentioned the quota was not included in the statement.

With the use of road, air and sea transport to the mission area in individual years the following were transported:

- 2019 - 436 tons;

- 2020 - 257 tons;

- until June $2021-174$ tons. 


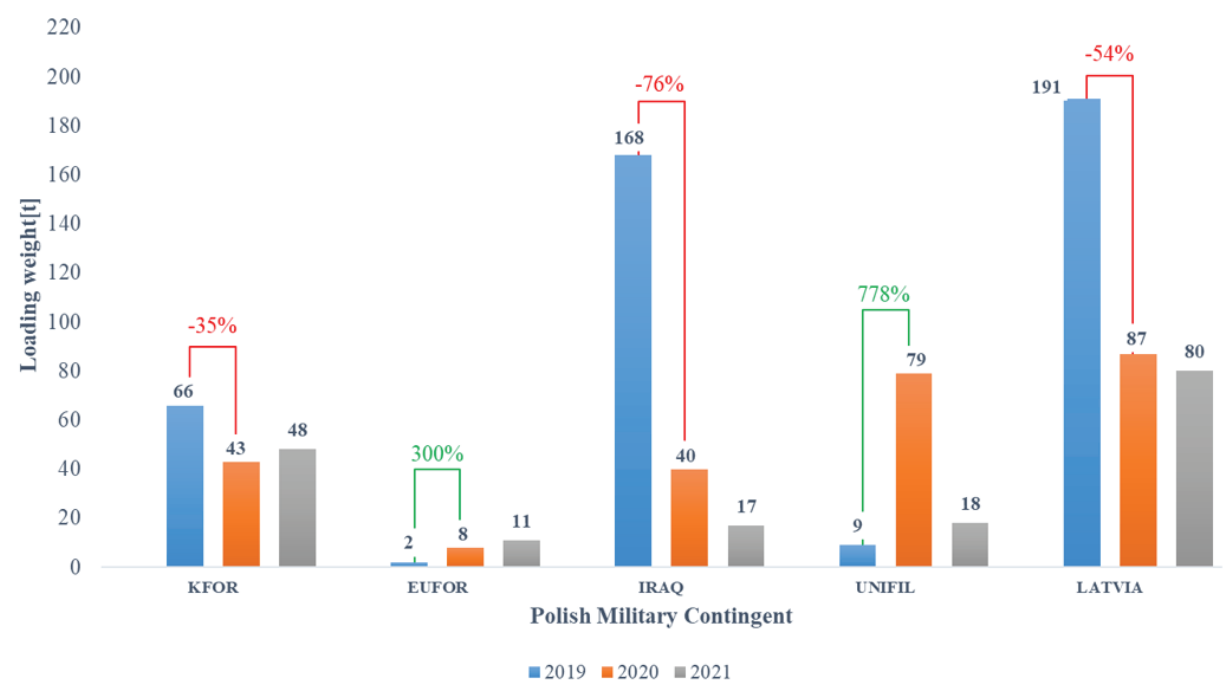

Fig. 11. Mass of material supplies delivered to the PKW area

Source: Prepared by the authors based on data from the 1st Logistics Brigade (Logistic Section)

At PMC KFOR, PMC IRAQ and PMC LATVIA in 2020 there was a decrease in the dynamics of transported loads by $35 \%, 76 \%$ and $54 \%$, respectively. In the case of a mission in Kosovo and Latvia, the above change was a direct result of international traffic restrictions caused by the spread of the COVID-19 coronavirus. Due to the above, road transport to the mission area was replaced by air transport, where, for economic reasons, materials that could not be obtained were transported in the mission area. It should be emphasized that at PMC LATVIA, the intensity of training and the use of combat agents, field rations and parts used to repair equipment has decreased. An additional factor influencing the realization of deliveries for PMC IRAQ was the operation phase. In 2019, the mission was at the stage of formation, which generated significant needs for the transfer of military equipment and equipment to the area. In the case of other missions, the index in 2020 increased by $300 \%$ for PMC EUFOR, and by $778 \%$ for PMC UNIFIL. The above fact resulted from the epidemiological situation in the world and the lack of availability of products on local markets. In addition, PMC UNIFIL was in the creation phase at the turn of 2019/2020.

When analyzing the amount of military property transported in the first half of 2021, it should be noted that the demand for domestic materials at PMC EUFOR and PMC KFOR is significantly higher than in previous years. This is due to the fact that deliveries are made using road transport, which is much cheaper than air transport and enables the transport of more materials, the availability of which is 
limited in local markets. It is estimated that due to the implementation of mandate tasks by PMC LATVIA, the weight of the load at the end of 2021 will be about 200 tons, at PMC IRAQ it will be at the level of 40 tons. A rotation of military vehicles is planned at PMC UNIFIL and due to the above, in 2021 it is planned to transport military property weighing about 80 tons.

\section{Implementation of tasks within the NATO response force}

In accordance with the strategic concept of conducting the activities of the North Atlantic Treaty Organization, the NATO Response Force is a multinational, joint force that should be capable of conducting independent low-intensity operations and participating in a large operation with the support of the Alliance forces. Separate sub-units must be prepared to operate outside their own country within a distance of no more than 5000 nautical miles, in a climate with temperatures ranging from $-32{ }^{\circ} \mathrm{C}$ do $+49^{\circ} \mathrm{C}$ (Poradnik formowania i przygotowywania pododdziałów przeznaczonych do dyżuru w Siłach Odpowiedzi NATO, Grupie Bojowej Unii Europejskiej oraz do realizacji Celów Sił Zbrojnych, 2011, s. 7-11).

The brigade actively carries out the logistic support tasks of the subunits assigned to the SON Sets. In 2020, nearly 180 soldiers and 135 equipment units were on duty as part of the heavy equipment transport company, NSE and contribution to JLSG HQ (Skulimowski, 2020, s. 9).

The greatest test of the skills acquired by subunits $1^{\text {st }}$ LOG BDE during the training and an opportunity to cooperate with allies in the theater of operations were the exercises certifying the 2016 NRF under the code name TRIDENT JUNCTURE- 15. The purpose of the exercise was to demonstrate allied capabilities in carrying out a multinational combined force exercise in the conditions of large-scale smuggling. About 36,000 soldiers from 30 countries participated in Spain, Portugal and Italy. The component separated by the Polish Armed Forces consisted of about 640 soldiers, over 200 vehicles and 8 aircraft (Romańczuk, 2015, access of the day 21.07.2021).

The $1^{\text {st }}$ Pomeranian Logistics Brigade was tasked with designating an NSE with a force of 45 soldiers and 16 vehicles for subunits deployed in Spain and Portugal (Delekta, Koncepcja zabezpieczenia logistycznego komponentu SZ RP wydzielanego do udziału w ćwiczeniu TRIDENT JUNCTURE 2015 (TRJE-15), 2015, s. 3). The difficulty of the task was determined by specific climatic and geographical conditions, distance, as well as the 2-month duration of the exercise.

The main tasks of the NSE during the exercise included (Delekta, Koncepcja zabezpieczenia logistycznego komponentu SZ RP wydzielanego do udziału w ćwiczeniu TRIDENT JUNCTURE 2015 (TRJE-15), 2015, s. 10):

- implementation of national logistics support tasks, as well as joining the allied logistics system managed by JLSG; 
- maintenance of the required inventory of class I materials, replacement fund for uniforms, the necessary inventory of tapes, consumables and spare parts;

- submitting demands, collecting, storing and delivering food products for the logistic company of the NATO's Combined Joint Chemical, Biological, Radiological and Nuclear Defence-Task Force (GZ OPBMR);

- fuel collection and distribution (ON) for sub-units of GZ OPBMR in the area of San Gregorio;

- coordination of the RSOM process in cooperation with JLSG;

- contracting local services and supplies during the exercise;

- implementation of ad hoc purchases on the local market;

- implementation and coordination of technical security based on about own capabilities, logistics company potential and HNS support;

- providing level 1 medical support;

- monitoring the general logistic situation of the national component during the exercise;

- submitting current logistic reports to JLSG and in the national system.

In the phase of preparation for the exercise, as part of reconnaissance, NSE soldiers carried out a market reconnaissance and signed contracts for sanitary and laundry services, rental of satellite terminals providing Internet access, local mobile network operator cards, waste disposal, car rental and an interpreter.

The transfer of individual components to / from the exercise area was carried out by air, road and sea transport. In the area where the main forces were deployed, Poland, as LN, secured the logistic needs reported by individual states included in the GZ OPBMR. Infrastructure and logistic devices were developed for over 400 soldiers from Poland, Great Britain, Italy, Romania, Hungary, the Czech Republic and Denmark (Delekta, Koncepcja zabezpieczenia logistycznego komponentu SZ RP wydzielanego do udziału w ćwiczeniu TRIDENT JUNCTURE 2015 (TRJE-15), 2015, s. 5).

NSE organized the logistic support according to the following rules (Delekta, Koncepcja zabezpieczenia logistycznego komponentu SZ RP wydzielanego do udziału w ćwiczeniu TRIDENT JUNCTURE 2015 (TRJE-15), 2015, s. 11):

- nutrition of the sub-units was provided in the form of fresh products and bottled water contracted by local suppliers indicated by HN. NSE picked up the products and delivered them to the logs they prepared and served meals;

- accommodation of sub-units was a national responsibility. They were organized based on NS-97 tents, accommodation and accommodation equipment;

- social and welfare services (waste disposal, access to industrial water, vehicle escort) under the support of the host country. Bathing, washing is secured by a local contractor; 
- diesel oil (F54) was supplied based on the French MCPU (Module Combined Petroleum Unit). Other POL products were in national responsibility;

- the provision of combat assets was carried out under national responsibility;

- technical protection (technical material, consumables, technical service) on one's own, and in the case of a range exceeding the possibilities of the log, as part of the purchase of the service on the local market;

- technical evacuation based on a Spanish unit;

- supplying the area with electricity with the use of own power generators.

Thanks to the use of the logistics potential of Inspectorate Armed Forces Support, close cooperation between NSE and logistics company and cooperation with the multinational logistics structures of JLSG, the logistics of GZ OPBMR SON 2016 was fully implemented.

\section{Final conclusions}

The article describes the mission, tasks and organizational structure of the $1^{\text {st }}$ Pomeranian Logistics Brigade from Bydgoszcz. Its role in the implementation of allied obligations under the Polish Military Contingent and SON was presented.

The following conclusions can be drawn from the analysis presented in the article:

1. 1st Logistics Brigade is a tactical union intended for logistic support of the PMC, operational troops and other institutions in the area of responsibility of the Inspectorate Armed Forces Support.

2. The organizational structure of the brigade is adapted to the implementation of the set goals and tasks, and the possibilities of mobile logistics potential fully cover the current needs.

3. Thanks to active participation in international exercises, soldiers and employees of the Ministry of National Defense expand their knowledge and skills, which they use to improve procedures and functional solutions.

4. PKW logistic support is implemented in a timely and collision-free manner thanks to experienced and qualified staff in the field of real logistic security.

5. In the future, $1^{\text {st }} \mathrm{LOG} \mathrm{BDE}$ will perform tasks in line with the directions set out in the Armed Forces Development Program in the field of providing logistic support for operational troops in the country and performing of tasks under the Polish Military Contingent, NRF and NATO capability targets.

Considering the above and the hypothesis put forward, it should be clearly stated that $1^{\text {st }}$ Pomeranian Logistics Brigade is the key link of the Polish Armed Forces intended for the implementation of logistic support tasks as intended. 


\section{BIBLIOGRAPHY}

[1] 1 Brygada Logistyczna, 2021. Informacje Ogólne [online]. Dostępne pod adresem: https://1blog. wp.mil.pl/pl/bip/info/w-informacje-ogolne/eon4-status-prawny/. [Dostęp dnia 18.07.2021].

[2] 1 Brygada Logistyczna, 2021. Zadania [online]. Dostępne pod adresem: https://1blog.wp.mil. $\mathrm{pl} / \mathrm{pl} / \mathrm{bip} / \mathrm{info} / \mathrm{w}$-informacje-ogolne/eon4-status-prawny/. [Dostęp dnia 18.07.2021].

[3] Delekta, M., (2015). Koncepcja zabezpieczenia logistycznego komponentu SZ RP wydzielonego do udziału w ćwiczeniu TRIDENT JUNCTURE 2015 (TRJE-15). Bydgoszcz: Inspektorat Wsparcia Sił Zbrojnych.

[4] Grala, D., (2017). Terytorialny system zabezpieczenia logistycznego w aspekcie wsparcia Polskich Kontyngentów Wojskowych realizujących zadania w operacjach wielonarodowych poza granicami kraju, Zeszyty Naukowe Akademii Sztuki Wojennej. Tom nr 1 (106). 66-78.

[5] Ministerstwo Obrony Narodowej, (2009). Instrukcja o przewozach wojsk oraz uzbrojenia i sprzętu wojskowego transportem lotniczym. Warszawa: Ministerstwo Obrony Narodowej, Sztab Generalny Wojska Polskiego.

[6] Ministerstwo Obrony Narodowej, (2015). Zasady wojskowego ruchu drogowego DU-4.4.4(B). Warszawa: Ministerstwo Obrony Narodowej, Dowództwo Generalne Rodzajów Sił Zbrojnych.

[7] Ministerstwo Obrony Narodowej, (2018). Zasady prowadzenia gospodarki materiałowej i finansowej w Polskich Kontyngentach Wojskowych realizujących zadania poza granicami państwa. Warszawa: Ministerstwo Obrony Narodowej, Dowództwo Generalne Rodzajów Sił Zbrojnych.

[8] Ministerstwo Obrony Narodowej, (2019). Doktryna Logistyczna Sił Zbrojnych RP D-4(B) wersja 2. Bydgoszcz: Ministerstwo Obrony Narodowej, Centrum Doktryn i Szkolenie Sił Zbrojnych.

[9] Ministerstwo Obrony Narodowej, (2020), Przepisy o działalności służby żywnościowej DU-4.21.1 (B). Bydgoszcz: Ministerstwo Obrony Narodowej, Inspektorat Wsparcia Sił Zbrojnych.

[10] NyszK, W., (2009). Zabezpieczenie logistyczne Polskich Kontyngentów Wojskowych w operacjach wielonarodowych, Warszawa: Akademia Obrony Narodowej.

[11] Poradnik formowania i przygotowywania pododdziałów przeznaczonych do dyżuru w Siłach Odpowiedzi NATO, Grupie Bojowej Unii Europejskiej oraz do realizacji Celów Sił Zbrojnych, (2011). Bydgoszcz: 1 Pomorska Brygada Logistyczna.

[12] Roмańczyк, M., (2015), Trident Juncture 2015 [online]. Dostępne pod adresem: https:// archiwum2019.mon.gov.pl/aktualnosci/artykul/wybrane/2015-09-21-trident-juncture-2015akredytacje-dla-mediow/ [Dostęp dnia 18.07.2021].

[13] Skulimowski, M., Zobowiązania sojusznicze i współpraca międzynarodowa 1 Pomorskiej Brygady Logistycznej z uwzględnieniem partnera strategicznego, XXVIII Międzynarodowy Salon Przemysłu Obronnego MSPO, Kielce, 9-10.09.2020 r., s. 9. 
